\title{
The Will Not to Believe
}

\author{
Joshua Cockayne, University of St Andrews \\ Jack Warman, University of York ${ }^{1}$
}

\begin{abstract}
Is it permissible to believe that God doesn't exist if the evidence is inconclusive? In this paper, we give a new argument in support of atheistic belief modelled on William James's 'The Will to Believe'. According to James, if the evidence for a proposition, $p$, is ambiguous, and believing that $p$ is a genuine option, then it can be permissible to let your passions decide. Typically, James's argument has been used as a defence of passionally caused theistic belief. However, in the existing literature, little attention has been given to topic of passionally caused atheistic belief. Here, we give much needed attention to the issue of how areligious passions can justify atheistic belief. Following James, we argue that if atheism is a genuine option for an agent, it is permissible to believe that God does not exist based on her hopes, desires, wishes, or whatever passions incline her to disbelieve. After defending the coherence of passionally caused atheism, we go on to suggest why this position is a tenable one for the atheist to adopt.
\end{abstract}

\section{Introduction}

William James's thesis, that it can sometimes be permissible to believe that $p$ on grounds that neither support nor deny the truth of $p$, has typically been used as a defence of fideistic theism. That is, James's thesis has typically been used to provide a defence of theistic belief, when the believer lacks sufficient evidential support for their belief. One such example of this use is John Bishop's (2007) defence of supra-evidential fideism. Yet, something which has often been overlooked in the discussion of Jamesian fideism is that James's thesis provides a justification not only for theistic belief, but also for atheistic belief. In this paper, we attempt to fill this lacuna

\footnotetext{
${ }^{1}$ The authors would like to thank David Efird for his helpful comments and feedback, as well as audiences at The Eastern Regional Meeting of the Society of Christian Philosophers at Rutgers University, The University of York Postgraduate Work in Progress Seminar and the White Rose Philosophy Postgraduate Forum for their invaluable questions and comments.
} 
by giving a new justification for atheistic belief. ${ }^{2}$ The key claims of this position are that when the evidence is ambiguous concerning God's existence and believing that God does not exist is a living, forced and momentous option, it is morally permissible to believe that God does not exist because of non-evidential passional causes. After outlining James's original thesis, we argue that the concept of passionally caused atheistic belief is not only possible, but also that passionally caused atheistic beliefs can meet the doxastic conditions required for permissibility as outlined by James.

We conclude by noting that this new defence of atheism provides a coherent alternative to William Rowe's (1979) 'friendly atheism' (which seeks to affirm both the atheist's and theist's justification for belief), since we avoid the supposed paradox of claiming that the atheist and the theist share the same grounds for their conflicting beliefs. According to our proposal, although the atheist and theist share the same rational grounds for belief, they have different passional grounds. Thus, we can maintain some of the intellectual modesty of Rowe's friendly atheism, but avoid what Rowe himself recognises as the paradoxicality of friendly atheism.

\section{James's Thesis}

As we go on to explain, James claims that it is not only permissible, but also necessary, that our passions decide our beliefs in cases where our decision is forced, momentous, and between live options, and when the question cannot be settled by intellectual means. We will call these Jamesian cases.

Religious belief presents one such case. As John Bishop describes, James is committed to defending a kind 'ambiguity thesis'. As he describes it,

The evidence is 'open' in the sense that it neither shows the truth of the claim that God exists nor the truth of its denial to be significantly more probable than not. The thesis then further describes this situation of open evidence as 'ambiguity' by making the claim that the total available evidence is systematically open to two viable competing interpretations. (2007, p. 71.)

\footnotetext{
${ }^{2}$ Sarah Adams and Jon Robson (2016) have recently defended an account of areligious experience as a justification for atheistic belief. In a similar vein, we aim to give much needed attention to the area of areligious passions as a justification for atheistic belief.
} 
This seem to be close to Pascal's concern, who, in a famous passage in his Pensées, confesses his anxiety about the lack of conclusive evidence of God in the world. He writes:

This is what I see and what troubles me. I look around in every direction and all I see is darkness. Nature has nothing to offer me that does not give rise to doubt and anxiety. If I saw no sign there of a Divinity I should decide on a negative solution: if I saw signs of a creator I should peacefully settle down in the faith. But, seeing too much to deny and not enough to affirm, I am in a pitiful state, where I have wished a hundred times over that, if there is a God supporting nature, she should unequivocally proclaim him, and that, if the signs in nature are deceptive, they should be completely erased; that nature should say all or nothing so that I could see what course I ought to follow. Instead of that, in the state in which I am, not knowing my duty. My whole heart strains to know what the true good is in order to pursue it: no price would be too high to pay for eternity. (L429)

Indeed, for Pascal, it seems our passions are necessary for belief in God. 'There is enough light for those who desire only to see,' he writes, 'and enough darkness for those of a contrary disposition' (L149). Pascal, it seems, was deeply troubled by the so-called ambiguity of the evidence for God's existence.

Yet, despite this ambiguity, for James, reason alone does not determine our beliefs. Rather, in these circumstances, our passional natures can determine our beliefs (2000/1897, p. 203). James summarises his thesis thus:

Ourpassional nature not only lawfully may, but must, decide an option between propositions, whenever it is a genuine option that cannot by its nature be decided on intellectual grounds; for to say, under such circumstances, "Do not decide, but leave the question open," is itself a passional decision,--just like deciding yes or no,--and is attended with the same risk of losing the truth. (2000/1897, p. 205)

This takes a little unpacking. A genuine option is one which is forced, momentous, and live. An option is forced when we must decide between a fixed number of options and with no alternative or choice to abstain or suspend judgement. For instance, a dilemma based on a logical disjunction, James notes (2000/1897, p. 199), forces one to decide between its disjuncts. Suppose one must choose whether or not to terminate a pregnancy. Either one terminates the pregnancy, or one does not. There is no option to abstain indefinitely from the decision, for to abstain indefinitely would be to allow the pregnancy to continue to full term. Therefore, the decision is forced. 
If an option is live for a subject, then the subject does not believe that option to be proven false, in the case of belief, or unfeasible, in the case of action. If an option is live for someone, James writes, then it appeals to their belief as a 'real possibility,' which makes an 'electric connection' (2000/1897, p. 199) with them. To illustrate this, James addresses his audience directly:

If I say to you: "Be a theosophist or be a Mohammedan," it is probably a dead option, because for you neither hypothesis is likely to be alive. But if I say: "Be an agnostic or be Christian," it is otherwise: trained as you are, each hypothesis makes some appeal, however small, to your belief. (2000/1897, p. 199.)

The thought is that, for some people, it remains to be settled finally whether they should commit to outright belief in Christianity or the suspension of their judgement, but it is settled whether other religious positions could be reasonably believed or lived by; the conclusion, for those people, is that they cannot be. For those people, Christianity and agnosticism are live options; other religious positions are not. ${ }^{3}$

An option is momentous when the stakes are high or the opportunity unique. James has us imagine that we are asked to join an Arctic expedition (2000/1897, p. 200). This is likely a unique opportunity and, given the risks involved, it seems the stakes are high too. So, the option is momentous. By contrast, suppose we must decide whether or not to read the latest novel by a popular author. The opportunity will arise again if we decide not to, and in either case, the decision will not have enormous consequences.

What, then, is our passional nature? 'Pure reason', James maintains, is not alone in establishing our beliefs, attitudes, and opinions. Rather, our 'willing nature' is also at work. Our willing or passional nature features such facts as '[f]ear and hope, prejudice and passion, imitation and partisanship, the circumpressure of our caste and set' (2000/1897, p. 203). When we find ourselves in a Jamesian situation, we simply must let our passional nature decide. And

\footnotetext{
${ }^{3}$ James supposes that his audience are protestants, and that for these protestants (at least), Islam is a dead option. We endorse neither of these presuppositions.
} 
given that we simply must let our passions decide in Jamesian cases, we are in the moral and epistemological clear for doing so. ${ }^{4}$

\section{Supra evidential atheistic fideism ${ }^{5}$}

James's thesis in 'The Will to Believe' has been hugely influential, particularly in the discussion of the rationality of religious belief and is a staple of undergraduate reading lists in the philosophy of religion. However, James's thesis is primarily used as a defence of theism. Bishop (2007), for instance, applies James's criteria to argue that since the evidence for and against the existence of God is ambiguous, perhaps necessarily so, it is morally permissible to believe that God exists for non-evidential reasons. ${ }^{6}$ Can the same kind of position be used to defend atheistic fideism? We think so. In this section, we argue that just as one might offer a moral justification of theistic

\footnotetext{
${ }^{4}$ As an anonymous referee helpfully points out, the argument for James's thesis, as presented here, is enthymematic. As well as holding that (i) we must decide, and (ii) reason doesn't decide, we would also have to hold that (iii) only reason or passion can decide. James doesn't provide an argument for (iii), and we won't explore (iii) in detail here. Possibly, James takes it as a matter of psychological fact that only reason and passion lead us to belief. The thought is that we cannot voluntarily form beliefs, but we are, in the ordinary course of our epistemic lives, pushed to believe by our passions. We should bear in mind how broad James' view of passions is.

${ }^{5}$ We take this name from a modification of Bishop's supra evidential theistic fideism.

${ }^{6}$ More specifically, Bishop maintains that
}

Where $\mathrm{p}$ is a faith-proposition of the kind exemplified in the context of theistic religious faith, it is morally permissible for people to take $\mathrm{p}$ to be true with full weight in their practical reasoning while correctly judging that it is not the case that p's truth is adequately supported by their total available evidence if and only if: The question whether p presents itself to them as a genuine option; and The question whether $\mathrm{p}$ is essentially evidentially undecidable' (2007, p. 147). 
belief in the face of evidential ambiguity, a defence of atheistic belief can be developed. To do this, we proceed to show that James's conditions can be met for atheistic belief.

First, it seems trivially true that atheism might be a living option for someone-that is, there is no reason to doubt the fact that it is possible for an atheistic worldview to be a worldview that makes sense to an individual and a world view that some individuals find appealing. The existence and extent of atheism stand obviously in support of this point. Jonathan Edwards, the Olympic triple jumper, writing on his loss of faith, highlights how a change in lifestyle or environment can make hypotheses live which were previously dead.

I never doubted my belief in God for a single moment until I retired from sport," he says. "Faith was the reason that I decided to become a professional athlete, in the same way that it was fundamental to every decision I made. It was the foundation of my existence, the thing that made everything else make sense. It was not a sacrifice to refuse to compete on Sundays during my early career because that would imply that athletics was important in and of itself. It was not. It was always a means to an end: glorifying God. (Matthew Syed, 2007.)

Although in Edwards's case, as he later goes on to admit, his loss of faith was attributed to being persuaded of the evidence against theism, this need not be the case. Indeed, atheism might become a live option for a theist simply by coming to the realisation that the evidence is more ambiguous than it first appeared, and no longer feeling drawn to theism as a belief system in the way described by Edwards.

Secondly, atheistic belief can be a forced option for someone. Here, the application of James's account is less straightforward. Remember, that for James, a forced option requires an agent to choose between disjuncts in such a way that choosing not to decide counts as choosing one of the disjuncts rather than the other. In the case of choosing whether or not to terminate a pregnancy, for instance, it is not possible to put off deciding indefinitely, such a course of action would essentially be to choose not to terminate the pregnancy. Yet, in the case of deciding whether or not to become or remain an atheist, refraining from decision seems entirely possible. Perhaps, the thought goes, one need not become a theist or an atheist, one might remain agnostic indefinitely.

Yet, James suggests, in a practical sense, endorsing agnosticism is no different to endorsing atheism. He writes that, 
To preach scepticism to us as a duty until 'sufficient evidence' for religion be found, is tantamount therefore to telling us, when in presence of the religious hypothesis, that to yield to our fear of its being error is wiser and better than to yield to our hope that it may be true. It is not intellect against all passions, then; it is only intellect with one passion laying down its law. (2000/1897, pp. 26-27.)

For James, all instances of non-theism, whether that be agnosticism or atheism have similar practical consequences, that is, they deny one the potential goods offered by theism. So, while it might be possible to put off deciding whether or not God exists, there is a certain sense in which agnosticism is a kind of practical atheism (or, perhaps, practical theism in some cases). To fill out this position more carefully, we borrow a distinction from Bishop's work between holding a proposition to be true and taking a proposition to be true. Bishop suggests that there are two elements to believing, namely 'bolding true and taking to be true in reasoning' (2007, p. 34; emphasis in the original). He illustrates their differences with the following example

Mary believes her pet tortoise is liable to roam, so, while she shows it off to her guests during tea on the lawn, she keeps a wary eye on it so as to avoid lengthy searching in the undergrowth at the bottom of the garden... Here Mary holds true the proposition that her tortoise can hide itself surprisingly quickly, and — now that she has set her tortoise at large— this belief becomes salient given her intention not to lose it. Through an effortless piece of practical reasoning in which, inter alia, she takes this proposition about the tortoise to be true there results Mary's action in keeping a close eye on it. (2007, p. 34; emphasis in the original.)

Taking to be true and holding to be true are both ordinary parts of our epistemic lives. ${ }^{7}$ Holding to be true is an involuntary attitude one has towards a proposition. Mary cannot, for instance, voluntarily bold the proposition that her tortoise can fly to be true. Taking to be true, on the other hand, is a voluntary attitude towards a proposition. Usually we only take to be true beliefs which we also hold to be true. Mary takes to be true the claim that her tortoise is able to hide itself partly because she holds it to be true that her tortoise is able to hide very easily. However, it is possible to take a proposition to be true even when one doesn't hold it to be true.

\footnotetext{
${ }^{7}$ Patrick Maher (1990) defends Bas van Fraassen's (1980) thesis that we can accept a hypothesis without believing it. Relatedly, Richard Holton (1994) explains how one can sometimes decide to trust someone, even if she does not believe that her trust will be vindicated.
} 
The agnostic seems to be an example of someone who refrains from holding it to be true that God does or doesn't exist, whilst taking it to be true that God doesn't exist. Now, let's consider the application of this distinction in the case of forced atheistic belief. Consider an individual who was raised to be an atheist and, after attending university, meets a group of students he considers his intellectual peers who believe that God exists. He comes to believe that his atheistic belief lacks conclusive evidential support. Nevertheless, he still holds the proposition that God does not exist to be true (perhaps this is his default position, as it were). Now, the student has to decide whether to continue to take this proposition to be true; when his friends invite him to church and ask him if they can pray together, the student has a forced decision: he must either continue to take his atheistic belief to be true, or to abandon it. More worryingly for the student perhaps, if his theistic peers are correct, then it makes a difference which way he responds. For if his peers are correct, and a loving God exists who desires relationship and union with him, and that this union makes some difference to his eternal existence, then he his forced to either deny that such a God exists or accept it.

The example outlined above puts pressure on the possibility of endorsing agnosticism. When faced with a decision of whether or not to engage in prayer, the student is forced to choose one of two disjuncts: Either she takes it to be true in her practical reasoning that God exists, or she doesn't. That is, she either takes atheism to be true or she takes theism to be true. It is not obvious, at least to us, what it would mean to take agnosticism to be true in one's practical reasoning in a case such as this.

What's more, there appear to be many more similar examples of such forced decisions. For instance, suppose one thinks that the moral permissibility of having an abortion depends on the truth or falsity or theism. Yet, one holds agnosticism to be true. The decision of whether or not to have an abortion might turn out, in a case such as this, to be present a forced option between atheism and theism for an individual. For whilst such an individual might continue to hold agnosticism to be true, they must take either theism or atheism to be true in such a case. That is, there are feasible cases in which one must be a practical theist or a practical atheist.

Yet, one might worry that the example we give is still not a forced option. One might remain agnostic or atheist indefinitely whilst still partaking in religious practices, say, in order to put Pascal's regimen to the test. ${ }^{8}$ Whilst this might seem initially plausible, there are reasons to

\footnotetext{
${ }^{8}$ With thanks to an anonymous referee for raising this objection.
} 
suppose that for some atheists and agnostics at least, eventually one's practical reasoning and doxastic reasoning have to unite. ${ }^{9}$ Christopher Jay (2018) suggests something similar in his discussion of atheistic practice. He writes that,

what makes the difference, amongst doxastic atheists, between those who are capable of an authentic form of religiosity and those (such as me) who are not is that those who are privilege certain religious claims or doctrines, in a way, by necessity. But what sort of necessity? Clearly they are not compelled to do so, or if they happen to be (if this is possible), it is not in virtue of that that they have the relevant sort of faith. Rather, the necessity in question is this: it is necessary for that person's (coherent) self-conception that they privilege that religious claim or doctrine over its rivals (i.e. over its negation and over treating all claims or doctrines about the subject matter equally or indifferently). The idea here is that for some people, given the way they have come - for whatever reason - to think of themselves, it would make no sense to treat the proposition that God exists as on a par with the proposition that God does not exist, or on a par with treating those propositions indifferently, in at least some contexts. This, I think, is what happens when a person who has become a doxastic atheist retains a special place in their thinking for the idea that God exists because that idea is crucial for their relating to a religious community in which they were raised. That community might not be just a community in which they were raised; it might also be in them, in the sense that their identification with it is part of what they recognise as their identity. (2018, p. 12.)

Whilst Jay gives a plausible example of an individual for which practical theism might be possible, he also identifies an example which appears to provide a case of a forced option. There are at least some individuals (and Jay's autobiographical admission suggests he may be one such case) for which practical theism remains impossible due to concerns for doxastic consistency. For such individuals, they cannot truly take it to be true that God exists by continuing to make

\footnotetext{
${ }^{9}$ We cannot take it for granted that agnosticism and atheism amount to the same option; not, at least, when we consider how atheism and agnosticism are incorporated into one's way of life. Marta Trzebiatowska (2018) writes that, as opposed to theist women: 'Atheist women do not follow a script because there is no script. They invent their own ways of being-in-the-world.' (2018, p. 3). Note that the script, so to speak, is still available for agnostics: It is not known to be false, but unknowable.
} 
petitions of God, whilst still holding atheism or agnosticism to be true. Such cases appear to show the possibility of genuinely forced decisions between atheism and theism. ${ }^{10}$

Lastly, this decision can clearly be a momentous one-if the student adopts this new worldview, his moral framework, his engagement with spiritual practices, his relationship with his family and friends, and even his hopes, desires and wishes will be transformed by taking theistic belief to be true. It seems fairly uncontentious, then, that atheistic belief can be a genuine option for someone.

Can atheistic beliefs have passional causes? This is the more contentious question concerning atheistic supra evidential fideism, we think. One might hold, for instance, that there is some connection between the truth of theism and the agent's passions. If atheism is true, can passional causes give us justification for believing or continuing to believe certain propositions? To answer this question, it will help to see a parallel discussion of the nature of (a)religious experiences and the justification of (a)theistic belief.

In their defence of areligious experience as a justification for atheistic belief, Sarah Adams and Jon Robson (2016) discuss whether experiences of God's absence can be veridical if atheism is true. ${ }^{11}$ They note that whilst experiences of God's absence from a particular place

\footnotetext{
${ }^{10}$ Similarly, as Robin le Poidevin (2016) suggests, whilst one could remain a religious fictionalist and engage in certain kinds of contemplative practice, practices such as petitionary prayer in which one expects or anticipates God to respond in some way, seem ruled out (2016, p. 186). He writes that, a religious fictionalist 'cannot but be aware that no one is there to grant her requests, and the attempt to make such a request will surely strike her as a sham' (2016, p. 186).

${ }^{11}$ For a version of the kind of objection Adams and Robson are interested in refuting, see C. Stephen Evans's book Natural Signs and Knowledge of God. Evans claims that
}

to be a natural sign, an experience or feature of the world would have to be caused by the reality it signifies, and there must be a natural disposition to become aware of that reality and form a belief about it. If God does not exist, there could hardly be a causal relation between a non-existent being and the suffering and evil in the world; nor does it make sense to say that the intended function of suffering and evil is to produce unbelief. (2010, p. 93, quoted in Adams \& Robson, 2016, p. 62.) 
might fail to be veridical, experiences of God's absence from the universe in general can count as veridical. 'It's certainly safe to say,' they argue,

that if the God of classical theism existed, the universe wouldn't be inhospitable to order or indifferent to our hopes and concerns; nor would the world be lacking in a deep and inbuilt significance. Thus, there is very plausibly a counterfactual link between atheism's being true and the relevant experiences being veridical. [...] Consider, for comparison, a standard case of apparent causation by absence; the absence of oxygen causing a match to fail to light. Defenders of causation by absence do not claim that some non-existent object (the oxygen in the room) causes the match to fail, but rather that some existing state of affairs does (viz., one that includes the oxygen's being absent). (2016, pp. 61-63.)

Our purpose here is not to defend Adams and Robson's claim that areligious experience justifies atheistic belief, but rather to show why the objection they are responding to won't be problematic for our account. If the agent has the kind of areligious experience which Adams and Robson describe, then the ambiguity thesis is simply false (at least for them). However, we're interested in discussing those individuals for whom the evidence is inconclusive, but, unlike areligious experiences, the moral permissibility of passionally caused belief is not dependent on veridicality at all — in fact, it makes little sense to talk of a passion being veridical or nonveridical. And thus, unlike Adams and Robson's account, we don't need to make the hypothetical claim that an agent's belief is justified if true. The moral permissibility of passionally caused belief is the same whether or not theism is true.

Thus, even if it turns out that atheism is false, it can be morally permissible to believe on passional causes (as long as the evidence is ambiguous and the option genuine). Is this claim plausible? It seems obviously the case that we do we find it morally permissible for people to decide on cases based on passional reasons, regardless of whether or not their hypothesis turns out to be true. Take for instance, James's example of the man who wonders whether to marry his partner:

It is as if a man should hesitate indefinitely to ask a certain woman to marry him because he was not perfectly sure that she would prove an angel after he brought her home. Would he not cut himself off from that particular angel-possibility as decisively as if he went and married someone else? (2000/1897, p. 215.)

It would seem, in this instance, that deciding to marry someone despite lacking concrete evidence whether or not she were an angel would be morally permissible, or, even 
recommended. And yet, it seems to make little difference to the moral point, whether or not she actually turns out to be an angel in permitting such a case.

'The Will to Believe' is, in part, James' response to Clifford's famous injunction that 'it is wrong, always, everywhere, and for every one, to believe anything on insufficient evidence' (1999/1877, p. 70). Clifford's thesis is that we have a moral duty not to believe anything on insufficient evidence; James' defences of religious belief and of deciding to marry (both of which he takes to require believing on insufficient evidence) are his attempts to provide counterexamples to that thesis. For James, the fear of error and of believing on insufficient evidence seems to lead to a kind of scepticism, which, he claims, 'is like a general informing his soldiers that it is better to keep out of battle forever than to risk a single wound. Not so are victories either over enemies or over nature gained. Our errors are surely not such awfully solemn things.' $(2000 /)$

Now we must wonder about the psychological possibility of passionally caused atheism. What would an areligious passion look like? One such example can be found in Thomas Nagel's discussion of his atheism:

I want atheism to be true and am made uneasy by the fact that some of the most intelligent and well-informed people I know are religious believers. It isn't just that I don't believe in God and, naturally, hope that I'm right in my belief. It's that I hope there is no God! I don't want there to be a God; I don't want the universe to be like that. (1997, p. 130.)

Note that Nagel does not appeal to evidence for rejecting the existence of God, and indeed, he seems to acknowledge the truth of something like the ambiguity thesis. Yet, Nagel does not believe in God because he hopes that God does not exist. Is such a position defensible, morally or epistemically? We've argued that there are good reasons to suppose so. ${ }^{12}$

What other reasons might a passionally caused atheist have to hope or desire that God does not exist? She might be pushed in that direction by reflection on the horrendous evil in the

\footnotetext{
${ }^{12}$ As an anonymous referee points out to us, Nagel makes an inference from his passional commitment to autonomy, to the truth of atheism, by constructing his Cosmic Authority problem. To present Nagel's example as a purely Jamesian case, we must imagine the dislike of God's existence as the root cause of Nagel's atheism, and not a secondary inference which might be made.
} 
world. In fact, it could be that even though the atheist's evidence for God's existence is ambiguous, her evidence supports belief in the proposition that if God exists, then she is either unwilling or unable to prevent that horrendous evil. The atheist does not know whether God exists, but she reasonably believes that God is indifferent to mankind. Her revulsion, resentment, or fear of an indifferent God might then provide the passional cause for her atheistic belief. She hopes that God does not exist, and that passion drives her to atheism.

Let's consider another example of passionally caused atheistic belief, based on Quine's rejection of an ontologically complex theory because of a 'taste for desert landscapes' (1948, p. 23). Whilst parsimony is often endorsed as a principle of rationality, what we say here neither undermines nor is undermined by that; all that is necessary for our point to stand is that it's possible that one have a passion for parsimony, indeed, Quine's use of the word 'taste' might imply something passional in nature. ${ }^{13}$ In fact, if our account is correct, then this is a good example of a passion required to justify not believing in God. That is, if the evidence for God's existence is ambiguous and one has a passion or inclination towards parsimony, then one is motivated not to believe on non-evidential grounds.

The notion of a parsimonious outlook as a passional cause seems to chime with what James has in mind regarding our willing nature. In his lectures on pragmatism, James compares tender- and tough-minded temperaments in philosophy. He characterises the irreligious person

${ }^{13}$ It might seem to some, that a desire for parsimony cannot be a passional cause. After all, Ockham's razor and Quine's preference for desert landscapes seem to be two sides of the same coin: The thought at the root of both is that on the balance of probabilities, parsimonious theories are more likely to be true, so we ought to have a preference for such theories.

Nevertheless, this does not rule out the possibility of someone's having a passion for parsimony that they neither explain, nor justify, with these epistemic considerations. Rather, it could be the case that a passion drives you to prefer parsimony. The notion that parsimony is valuable for more than its epistemic value is not unprecedented in analytic philosophy. Writing of Harry Frankfurt's The Reasons of Love (2004), Philip L. Quinn writes: 'The book's dust jacket claims that it is beautifully written. Its literary qualities seem to me to resemble the sharp lines and bright colors of a fine Mondrian or the austere elegance of good modernist architecture, not the rich chiaroscuro of a Titian or the exuberance of a baroque cathedral. Frankfurt's prose will prove to be particularly attractive to those with the taste for desert landscapes whose cultivation is highly recommended in contemporary analytic philosophy (2004).' 
as 'Empiricist [...], Materialistic, Pessimistic'. This stands in contrast with the religious person as 'Rationalistic [...], Idealistic, Optimistic' (2000/1907, p. 11). On James' view, it is an underappreciated truth our temperaments are fundamental to the shaping of our philosophical outlooks too.

Of whatever temperament a professional philosopher is, he tries, when philosophizing, to sink the fact of his temperament. [...] Yet his temperament really gives him a stronger bias than any of his more strictly objective premises. It loads the evidence one way or the other, making for a more sentimental or a more hard-hearted view of the universe, just this fact or that principle would. He trusts his temperament. Wanting a universe that suits it, he believes in any representation of the universe that does suit it. (Italicised in the original. 2000/1907, pp. 8-9.)

Of course, we are not committed to the particulars of James's analysis here; the important idea is that our temperaments can play the role of passional causes. 


\section{Is supra-evidential atheistic fideism a tenable hypothesis?}

One line of objection to our claim might follow the thought that atheist belief is usually held on the intellectual grounds which we claim do not settle the matter. For instance, one might argue that atheism is usually held (by most atheists) to be justified by arguments stemming from evil, divine hiddenness, and divine superfluity. In part, so the objection goes, the reason atheists pursue this line of argument against theistic belief is that it manifests their commitment to certain intellectual virtues, or their intellectual temperament. The point is that while atheistic beliefs could be passionally caused, it is unlikely that they are consistent with the intellectual commitments of many atheists.

In the first instance, it is worth noting that the questions of whether or not passionally caused atheism is possible and whether it is an attractive proposal to atheists are different questions which need not have the same answer. Even if it could be shown that some atheists will find this position unsatisfying, we have still managed to stake out a logical space for such a position, which we think has its merits as a defence of atheism.

It is also important here to stress the significance of the ambiguity claim to atheistic fideism. Whilst surely one could be passionally inclined towards believing that there is no such thing as fairies, or that there are no monsters under the bed, for example, these are not cases which merit moral justification since the evidence is not ambiguous (or at least we assume not). I have good evidence concerning the existence or nonexistence of fairies-all the reported sightings have been dubious, there are no reasons to suggest that there are fairies, and fairies seem to be incompatible with a scientific account of what things exist. Clearly then, the evidence for fairies is not ambiguous, but rather, weighs heavily in the favour non-existence. The same too will apply to monsters under the bed, the Loch Ness monster, and Russell's teapot. ${ }^{14}$ The defence of atheism we provide does not claim that we can believe that things don't exist if we are inclined in the correct way. But rather, if the evidence is ambiguous and not believing in

\footnotetext{
${ }^{14}$ Of course, it might be possible, as an anonymous referee points out, that perhaps we have not encountered a true believer in Russell's teapot, who says that the absence of definitive sightings does not decide the case and is passionate about his or her belief.
} 
something is a live option, then we are justified in not believing. So, to claim that there are good arguments in favour of atheism, is merely to reject the ambiguity thesis.

The project that we are developing here is not supposed to convince the atheist who already thinks she has good reasons not to believe in God that in fact she need only appeal to her passions. Rather, we have in mind someone similar to Bishop's 'reflective theist' (or, 'reflective atheist' in our case), that is, someone who is genuinely concerned about whether or not their atheistic beliefs are true but isn't fully swayed by the evidence on either side, and thus finds herself with no good evidential reasons to give up her belief or to continue believing. What can be said in defence of this person's continuing to believe or their giving up belief? Simply noting that most atheists are persuaded by the relevant evidence will be of little comfort.

It will be helpful here to see how a reflective atheist might respond to arguments which some atheists typically take to be conclusive, if our thesis is correct. Consider the evidential problem of evil. This argument, very simply, claims that the existence of gratuitous suffering has a much higher probability on atheism than it does on theism. And since there really does seem to be gratuitous suffering, we should - it is said - conclude that atheism is more probably true than theism. However, there are also a multitude of theodicies which purport to show why this is not the case. What if Jim, after reading both William Rowe (1979) and Eleonore Stump (2010) finds himself equally persuaded by both sides? One response is that Jim's reaction to the problem of evil can be recast as a passion rather than an inference. Suppose Jim has heard a lot about the suffering in the world. War, famine, poverty, disease, and so on, all stir a deep emotional response in him. Jim views the world as a cruel, violent, and hopeless place. All this happens without much reflection on theism or atheism. Jim learns that some people believe that there exists an omnipotent, omnibenevolent, omniscient God. Moreover, this belief in the existence of God is foundational for much of their moral beliefs and behaviours. Then one day, Jim finds himself in a Jamesian situation. He encounters various arguments for and against the existence of God but none seems to settle the question. And yet, his decision is forced. So, what does Jim have to go on? His passional response to the gratuitous suffering he has observed in the world inclines him to atheism. He does not believe that atheism is better supported by the evidence, but nevertheless he is still morally justified in acting upon his belief that atheism is true.

When challenged, though, Jim still appeals to the problem of evil. How do we explain this without undermining our claim that atheism can be passionally caused? Recall that, as James said, 'our reason is quite satisfied in nine hundred and ninety-nine cases out of every thousand of 
us, if it can find a few arguments that will do to recite in case our credulity is criticized by some one else' (2000/1897, p. 203). So, in this case, it seems that while one's atheism is caused by a passional response to evil, one is still able to appeal to argument in its defence.

\section{Conclusion: Friendly atheism and the will not to believe}

Typically, in giving a defence of atheism, the atheist attempts to undermine or defeat theistic belief in some way. That is to say, atheistic arguments ordinarily provide negative justification for why the belief that God exists is unreasonable or unjustified. If the position we have developed here is at all plausible, then we have provided a positive defence for the atheist which doesn't require her to show that theism is false (only that the evidence in favour of/against theism is ambiguous). Thus, for the atheist who finds the arguments on both sides inconclusive, but who feels inclined towards the belief that God does not exist, we offer some justification for her disbelieving or continuing to disbeliever.

It is worth noting that one virtue of our position is that it promotes a more tolerant attitude towards disagreement. It is a kind of friendly atheism which recognises that regardless of whether God exists, some theists' beliefs in the existence of God are justified. William Rowe's original exposition of this view is motivated by his observation that one can have rational grounds for a false belief (1979, p. 40). However, this position becomes paradoxical, he thinks, when the atheist and the theist share their grounds for their respective beliefs, or when they might be reasonably expected to do so.

One point of contrast between our proposal and Rowe's is that passionally-caused friendly atheism doesn't become paradoxical because the atheist and the theist do not share rational grounds, although their beliefs are passionally caused. There is nevertheless a symmetry to the appeal to passionally-caused (a)theistic belief which promotes tolerance between theists and atheists. In accepting passionally-caused atheism, not only does the atheist adopt a position which cannot be easily criticized by the theist, she also adopts a position of common ground with the passionally-caused theist. Supra-evidential atheistic fideism therefore allows us to endorse a more permissive notion of friendly atheism. 


\section{References}

ADAMS, Sarah \& ROBSON, Jon. 2016. 'Does absence make atheistic belief grow stronger?,' International Journal for the Pbilosophy of Religion, Vol. 79, Issue 1: pp. 49-68.

BISHOP, John. 2007. Believing by Faith: An Essay in the Epistemology and Ethics of Religious Belief. (Oxford: Clarendon University Press).

CLIFFORD, William K. 1877. "The ethics of belief' in The Ethics of Belief and Other Essays, Madigan, T. (ed.), (Amherst, MA: Prometheus, 1999), pp. 70-96.

CULLISON, Andrew. 2013. 'Seemings and Semantics' in Tucker, 2013.

DRAPER, Paul. 1989. "Pain and Pleasure: An Evidential Problem for Theists," Nous Vol. 23, No. 3: pp. 331-50.

EVANS, C. Stephen. 2010. Natural Signs and Knowledge of God: A New Look at Theistic Arguments (Oxford: Oxford University Press).

HOLTON, Richard. 1994. 'Deciding to trust, coming to believe,' Australasian Journal of Philosophy Vol. 72, No. 1: pp. 63-76.

JAMES, William. 1897. 'The Will to Believe' from Pragmatism and Other Writings, Gunn, G. (ed.) (USA: Penguin Books, 2000), pp. 198-219.

JAMES, William. 1907. 'The Present Dilemma in Philosophy' from Pragmatism and Other Writings, Gunn, G. (ed.) (USA: Penguin Books, 2000), pp. 7-23.

JAY, Christopher. 2018. 'Doxastic and Nondoxastic Atheisms' in Atheisms: The Philosophy of Nonbelief, (eds). Victoria Harrison \& Harriet Harris (Routledge), pp. 1-13.

LE POIDEVIN, Robin. 2016. 'Playing the God Game' in Alternative Concepts of God, edited by Andrei A. Buckareff and Yujin Nagasawa (Oxford: Oxford University Press).

MAHER, Patrick. 1990. 'Acceptance without Belief,' PS A: Proceedings of the Biennial Meeting of the Philosophy of Science Association Vol. 1990: pp. 381-392.

NAGEL, Thomas. 1997. The Last Word. (Oxford: Oxford University Press).

PASCAL, Blaise. 1670. Pensées. Translated by A. J. Krailsheimer. (London: The Folio Society, 2011). 
QUINE, Willard. V. O. 1948. 'On What There Is,' Review of Metaphysics Vol. 2, No. 5: pp. 21-38.

QUINN, Philip L. 2004. Review of The Reasons of Love by Harry Frankfurt, Notre Dame Philosophical Reviews [Online] https://ndpr.nd.edu/news/the-reasons-of-love/ [accessed 21/2/2018.]

ROWE, William L. 1979. ‘The Problem of Evil and Some Varieties of Atheism,' American Philosophical Quarterly Vol. 16, No. 4: pp. 335-41.

STUMP, Eleonore. 2010. Wandering in Darkness: Narrative and the Problem of Suffering. (Oxford: Oxford University Press.)

SYED, Matthew. 2007. “I have never been happier" says the man who won gold but lost God' The Times (London), 27 June 2007 [Online] https://www.thetimes.co.uk/article/i-havenever-been-happier-says-the-man-who-won-gold-but-lost-god-jmslbj385c7 [accessed 24 July 2018.]

TRZEBIATOWSKA, Marta. 2018. ‘Sovereign of Herself: Women’s Narratives of 'Lived Atheism,' Secularism and Nonreligion, Vol. 7, No. 1, pp. 1-11.

TUCKER, Chris (ed.). 2013. Seemings and Justification: New Essays on Dogmatism and Phenomenal Conservatism. (Oxford: Oxford University Press.)

VAN FRAASSEN, Bas. C. 1980. The Scientific Image. (New York: Oxford University Press.) 